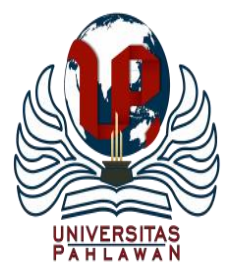

Edukatif : Jurnal Ilmu Pendidikan Volume 3 Nomor 3 Tahun 2021 Halm 880-889 EDUKATIF: JURNAL ILMU PENDIDIKAN

Research \& Learning in Education

https:/ledukatif.org/index.php/edukatif/index

\title{
Analasis Efektifitas Pembelajaran Daring Dalam Menghadapi Wabah Pandemi Covid-19
}

\author{
Dwinda Nur Baety ${ }^{1 凶}$, Dadang Rahman Munandar $^{2}$ \\ Universitas Singaperbangsa Karawang, Indonesia ${ }^{1,2}$

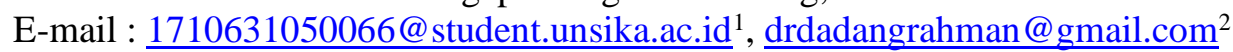

\begin{abstract}
Abstrak
Tujuan dari penelitian ini adalah untuk menganalisis efektifitas pembelajaran daring ditinjau dari akses pendukung terlaksananya pembelajaran daring yang paling banyak digunakan pada peserta didik jenjang menengah hingga perguruan tinggi serta faktor-faktor yang dapat mempengaruhi efektivitas pembelajaran daring. Metode penelitian yang digunakan adalah deskriptif kualitatif. Teknik pengumpulan data menggunakan kuisioner. Responden pada penelitian ini adalah 118 peserta didik di Kabupaten Bekasi. Data dianalisis dengan teknik kualitatif. Berdasarkan hasil kuisioner, 63\% responden menyatakan bahwa pelaksanaan pembelajaran daring belum efektif. Akses pendukung pembelajaran daring yang paling banyak digunakan adalah Google classroom dengan 72,9\% pengguna dan dilengkapi fitur-fitur yang cukup membantu pelaksanaan daring. Hasil kuisioner menunjukan bahwa efektifitas dari pembelajaran daring dipengaruhi oleh faktor ekonomi (38\%), faktor sosial (30\%), faktor Kesehatan (19\%) dan faktor kepribadian (13\%). Terakhir, saran peserta didik untuk meningkatkan efektifitas pembelajaran daring bagi para tenaga pendidik yaitu: 1) meringkas materi belajar yang perlu di unduh; 2) menggunakan virtual meeting hanya untuk menjelaskan teori yang sekiranya sulit dipahami; 3) menghindari pemberian tugas yang berlebihan; 4) Selalu menanyakan kepada peserta didik terkait materi yang kurang dimengerti secara berkelompok/individu; 5) memberikan informasi terkait forum diskusi/webinar untuk melatih beradaptasi daring; 6) melaksanakan pembelajaran sesuai dengan jadwal; 7) menggunakan sistem/platform yang sama sebagai media pembelajaran daring.
\end{abstract}

Kata Kunci: COVID-19, Pembelajaran Daring, Akses Belajar, Faktor-Faktor Efektifitas Daring.

\begin{abstract}
The aims of this study was to analyze the effectiveness of online learning in terms of media access that support for implementation online learning which is mostly used for students from high school student to university and the factors that can affected the effectiveness of online learning. Method of research is descriptive qualitative. The data collection technique used a questionnaire. The respondents who taken for this research were 118 students in Bekasi regency area. Data were analyzed using qualitative techniques. Based on the results of the questionnaire, $63 \%$ of respondents stated that the implementation of online learning was still ineffective. The most used access to support the online learning is google classroom for $73 \%$ users with sufficient features that assist online learning. The result of the questionnaire found that the effectiveness of online learning is influenced by economic factors (38\%), social factors (30\%), health factors (19\%) and personality factors (13\%). Finally, the suggestions to improve the effectiveness of online learning for educators are; 1) summarizing the learning materials that would be downloaded; 2) using virtual meetings only to explain theories that are difficult to understand; 3) avoiding redundant assignments; 4) Always ask students regarding material that is not understood in groups / individually; 5) provide information related to discussion forums / webinars to adapting online learning; 6) keep learning according to the schedule; 7) using the same system / platform as online learning media.
\end{abstract}

Keywords: COVID-19, Online Learning, Access Learning, Effectiveness of Online Learning Factors.

Copyright (c) 2021 Dwinda Nur Baety, Dadang Rahman Munandar

$\triangle$ Corresponding author

Email : $\underline{1710631050066 @ \text { student.unsika.ac.id }}$

DOI : https://doi.org/10.31004/edukatif.v3i3.476

ISSN 2656-8063 (Media Cetak)

ISSN 2656-8071 (Media Online)

Edukatif : Jurnal Ilmu Pendidikan Vol 3 No 3 Tahun 2021

p-ISSN 2656-8063 e-ISSN 2656-8071 


\section{PENDAHULUAN}

Belakangan ini, dunia tengah dihebohkan dengan adanya penyebaran virus baru yang sangat pesat, tidak terkecuali bagi Indonesia. Virus Corona atau yang dikenal dengan COVID-19 saat ini diketahui telah menginfeksi jutaan orang di dunia. COVID-19 telah dinyatakan sebagai pandemi oleh Organisasi Kesehatan Dunia (WHO) karena telah menyebar ke lebih dari 100 negara di dunia. Menurut KBBI, pandemi adalah suatu wabah yang menjangkiti banyak orang dan menyebar ke geografi yang sangat luas. WHO mendefinisikan pandemi sebagai situasi dimana seluruh penduduk dunia kemungkinan besar akan terinfeksi dan berpotensi jatuh sakit.

Pandemi COVID-19 berdampak pada hampir semua sektor kehidupan seperti ekonomi, kesehatan, sosial, dan pendidikan. United Nations Educational, Scientific and Cultural Organization (UNESCO) menyatakan, penyebaran COVID-19 berdampak pada sektor pendidikan di seluruh dunia dan mengancam hak-hak pendidikan para peserta didik di masa depan. Sektor pendidikan di Indonesia tidak luput dari adanya COVID-19 dan ikut merasakan dampak dari penyebaran virus tersebut (Dewi, 2020). Sekitar 60 juta anak usia sekolah di Indonesia dari 1,5 milyar anak di 188 negara dunia telah terkena dampak dari COVID-19 (Putria dkk., 2020). Dampak yang paling dirasakan oleh peserta didik adalah perubahan penyelenggaraan pelayanan di instansi pendidikan, seperti sekolah formal disemua jenjang, sekolah nonformal, hingga perguruan tinggi.

Dalam surat edaran Kemendikbud Nomor 4 Tahun 2020 tentang Pelaksanaan Kebijakan Pendidikan dalam Masa Darurat Penyebaran Coronavirus Disease (COVID-19) yang dikeluarkan oleh pemerintah sebagai tindakan solusi untuk tetap dapat mewujudkan Pendidikan yang efektif, salah satu kebijakannya adalah proses belajar mengajar dilakukan dari rumah secara daring atau pembelajaran jarak jauh untuk mencegah penyebaran virus di lingkungan pendidikan (Santoso, 2020). Dalam memenuhi kebijakan pemerintah tersebut, tentunya banyak peserta didik yang mengharuskan dirinya mempunyai aplikasi layanan pendidikan. Bahkan banyak startup di bidang pendidikan seperti ruang guru, zenius, quipper, dan titik pintar yang turut mendukung kebijakan pemerintah dengan memberikan layanan secara gratis seiring mewabahnya COVID-19 (Burhan, 2020).

Daring sendiri merupakan akronim dari dalam jaringan yang bermakna saling bertukar informasi dengan media yang terhubung via jaringan internet. Menurut Isman (Dewi, 2020), pembelajaran daring merupakan suatu proses interaksi pembelajaran dengan menggunakan komputer dan akses internet. Pembelajaran daring adalah suatu implementasi dari proses belajar mengajar dengan saling bertukar informasi menggunakan jaringan internet untuk mendapatkan target yang lebih masif (Bilfaqih \& Qomarudin, 2015). Melalui pemanfaatan perkembangan teknologi informasi dan komunikasi, sistem pembelajaran secara online dinilai menjadi alternatif yang paling memungkinkan saat ini untuk keberlangsungan pembelajaran dengan tetap menjaga jarak demi mencegah penyebaran virus corona dan mematuhi aturan untuk tidak berkumpul di satu tempat. Pembelajaran daring dengan penggunaan jaringan internet dapat diadakan dan diikuti secara gratis atau dengan biaya tertentu.

Hasil kuisioner peneliti yang diberikan kepada responden melalui googleform dari jenjang sekolah menengah hingga perguruan tinggi diperoleh 96,6\% dari 118 responden telah mengetahui arti dari pembelajaran daring. Hal ini berarti sebagian besar sekolah dan perguruan tinggi telah melaksanakan himbauan dari Menteri Pendidikan dan Kebudayaan Indonesia untuk melakukan pembelajaran jarak jauh melalui daring selama masa pandemi COVID-19. Dasar pembelajaran daring adalah peserta didik dapat mengakses sumber belajar dan materi pembelajaran tanpa dibatasi oleh waktu dan tempat (Kurniasari dkk., 2020). Peserta didik yang diharuskan belajar secara daring tentunya berdampak pada sistem pengajaran guru yang juga harus dapat memfasilitasi peserta didik untuk belajar dari rumah. Ada berbagai macam platform yang menyediakan jasa edukasi ini, diantaranya: Rumah Belajar dari kemendikbud, google classroom, Edmodo, ruang guru, zenius, Microsoft office 365 for education, google suite for education, sekolahmu, kelas 
pintar dan platform edukasi lainnya Menurut Wisudawati dkk. (2020) platform pembelajaran online dapat memberikan dampak positif terhadap proses pembelajaran jika dipahami oleh penggunanya. Namun, penetapan aturan pembelajaran daring yang cukup mendadak menyebabkan kesiapan mayoritas instansi Pendidikan tidak maksimal bahkan hampir tidak ada sama sekali.

Dengan mempertimbangkan situasi saat ini dan melihat kondisi dunia yang tengah dilanda wabah COVID-19 maka pendidikan Indonesia membutuhkan pembelajaran daring untuk melanjutkan proses pembelajaran namun tetap mengedepankan kesehatan. Maka, munculah suatu kebutuhan akan media yang diharapkan mampu menyampaikan pembelajaran dengan baik dan tepat. Wina Sanjaya (Hidayah dkk., 2020) menyebutkan bahwa pemilihan media pembelajaran mempertimbangkan beberapa aspek seperti tujuan yang akan dicapai, karakteriktik peserta didik, kondisi lingkungan, konsep yang jelas dan sesuai dengan gaya belajar peserta didik. Laili \& Nashir (2021) menyatakan media pembelajaran online yang mudah diakses dan dapat mendukung pembelajaran berpengaruh terhadap hasil dari proses belajar mengajar. Sehingga, penggunaan media yang tepat sangat dibutuhkan untuk dapat memberikan akses pembelajaran yang maksimal bagi peserta didik selama masa darurat COVID-19. Karena hal itulah peneliti ingin mengetahui jenis media daring yang paling banyak digunakan oleh peserta didik di jenjang menengah hingga perguruan tinggi.

Di dalam bukunya yang berjudul The One World Schoolhouse, Salman Khan (Bilfaqih \& Qomarudin, 2015) mengatakan bahwa pendidikan tidak hanya terbatas pada ruang yang menghubungkan telinga murid dengan mulut guru. Namun Pendidikan adalah apa yang didapatkan dan dicerna dari masing-masing pikiran. Hal ini menunjukkan bahwa pembelajaran sejatinya masih tetap dapat berjalan tanpa harus melakukan kontak secara langsung. Sejalan dengan penelitian Yunitasari dan Hanifah (2020) bahwa kelangsungan pembelajaran selama pandemi sangat bergantung dari faktor kesiapan sekolah, siswa dan guru. Namun faktor-faktor eksternal yang dapat mempengaruhi keefektifan dari pembelajaran daring tetaplah ada dan sangat penting untuk diketahui sehingga kendala dari proses pembelajaran daring dapat diminimalisir.

Kajian mengenai efektifitas pembelajaran daring pernah dilakukan oleh beberapa peneliti sebelumnya. Berdasarkan data terbaru, (1) Abidin dkk. (2020) mengkaji tentang efektifitas pembelajaran jarak jauh ditinjau dari pemahaman terhadap materi pelajaran; (2) Daheri dkk. (2020) tentang efektifitas WhatsApp sebagai media belajar daring; (3) Mustakim (2020) mengkaji efektifitas pembelajaran daring selama pandemi ditinjau dari penggunaan media online dalam pembelajaran matematika; (4) Putria dkk. (2020) menganalisis guru untuk mendapatkan faktor pendukung dan penghambat guru dalam pelaksanaan pembelajaran daring; (5) Laili \& Nashir (2021) membahas persepsi mahasiswa terkait pembelajaran daring. Berdasarkan referensi tersebut, kajian mengenai akses pendukung pembelajaran daring yang paling banyak digunakan pada peserta didik jenjang menengah hingga perguruan tinggi, kelebihan dan kekurangannya, serta faktor-faktor yang menurut peserta didik mempengaruhi efektifitas pembelajaran daring pada masa pendemi COVID-19 belum pernah dilakukan.

Dengan demikian, penelitian ini diharapkan dapat menjadi referensi bagi para guru/dosen untuk memilih media yang dapat memfasilitasi pembelajaran daring dan tanggapan yang diperoleh dari para responden terkait faktor-faktor yang mempengaruhi pembelajaran daring dapat menggambarkan keadaan peserta didik dalam proses belajar mengajar di tengah pandemi saat ini sehingga bisa menjadi rujukan dalam menentukan kebijakan-kebijakan baru terhadap pembelajaran daring kedepannya.

\section{METODE}

Metode dalam penelitian ini menggunakan metode deskriptif dengan pendekatan kualitatif untuk menganalisis suatu fenomena yang akan diteliti melalui dukungan studi kepustakaan sehingga memperkuat hasil dari penelitian yang didapatkan dalam pembuatan kesimpulan. Penjabaran statistik dan pendeskripsian data didasarkan pada jawaban kuisioner siswa. Adapun langkah-langkah dalam pelaksanaan metode deskriptif menurut Salim \& Haidir (2019) adalah sebagai berikut; (1) Perumusan masalah, (2) menentukan 
jenis informasi yang dibutuhkan, (3) menentukan prosedur pengumpulan data, (4) menentukan informasi dalam prosedur penggelolaan data, dan (5) menarik kesimpulan penelitian. Objek penelitian ini adalah kegiatan pembelajaran daring selama masa pendemi COVID-19.

Sumber data primer didapatkan responden sebanyak 118 peserta didik. Sedangkan data sekunder berasal dari buku referensi dan jurnal-jurnal terkait efektifitas pembelajaran daring. Untuk mendapatkan data yang optimal, peneliti menyebarkan kuisioner melalui link googleform yang diisi oleh peserta didik dari jenjang menengah hingga perguruan tinggi di wilayah kabupaten Bekasi. Kuisioner terdiri dari 8 pernyataan dengan 4 pernyataan tertutup dan 4 pernyataan terbuka. Teknik analisis yang digunakan dalam penelitian ini menggunakan model analisis kualitatif Miles dan Huberman (Sugiyono, 2015) dengan menekankan pada efektifitas pembelajaran daring menurut peserta didik selama pandemi COVID-19 dari pengumpulan data, reduksi data, penyajian data dan penarikan kesimpulan. Berikut adalah diagram alur dari analisis kualitatif:

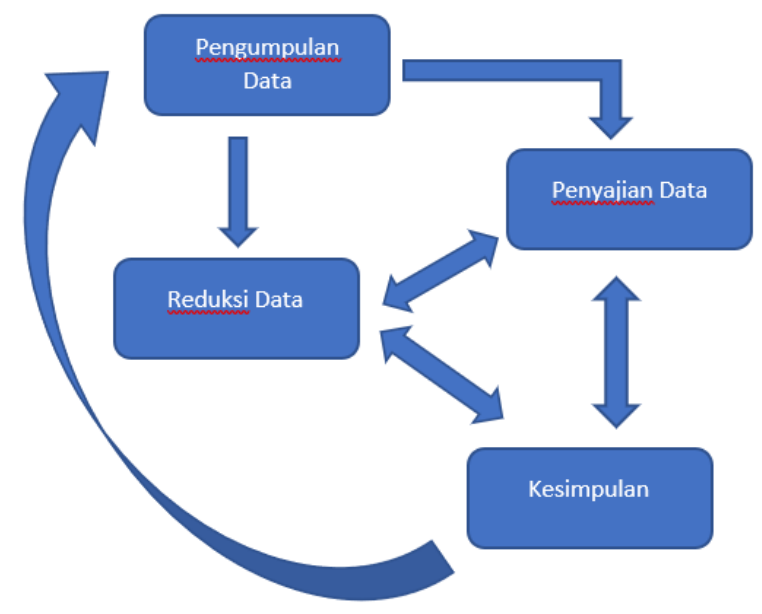

Gambar 1 Diagram Alur Analisis Kualitatif.

\section{HASIL DAN PEMBAHASAN}

Dari angket yang disebar melalui link googleform diperoleh data dari 10 siswa jenjang SMP/sederajat, 25 siswa jenjang SMA/sederajat dan 83 mahasiswa terkait akses-akses yang mendukung terlaksananya pembelajaran daring, kekurangan dan kelebihan dari platform tersebut serta faktor-faktor yang dapat mempengaruhi efektivitas pembelajaran daring dari aspek positif dan negatifnya. Berikut merupakan statistik jawaban responden beserta deskripsi terhadap pernyataan yang diberikan.

\section{Keefektifan Pembelajaran Daring Menurut Peserta Didik}

Hasil kuisioner menunjukkan bahwa 63\% dari 118 responden atau sebanyak 75 peserta didik mengaku bahwa pembelajaran daring di instansi pendidikan mereka masih belum efektif dan $37 \%$ sisanya atau sebanyak 43 peserta didik merasa pembelajaran daring disekolahnya sudah efektif.(Gambar 2) 


\section{Apakah menurutmu pembelajaran daring disekolahmu sudah efektif?}

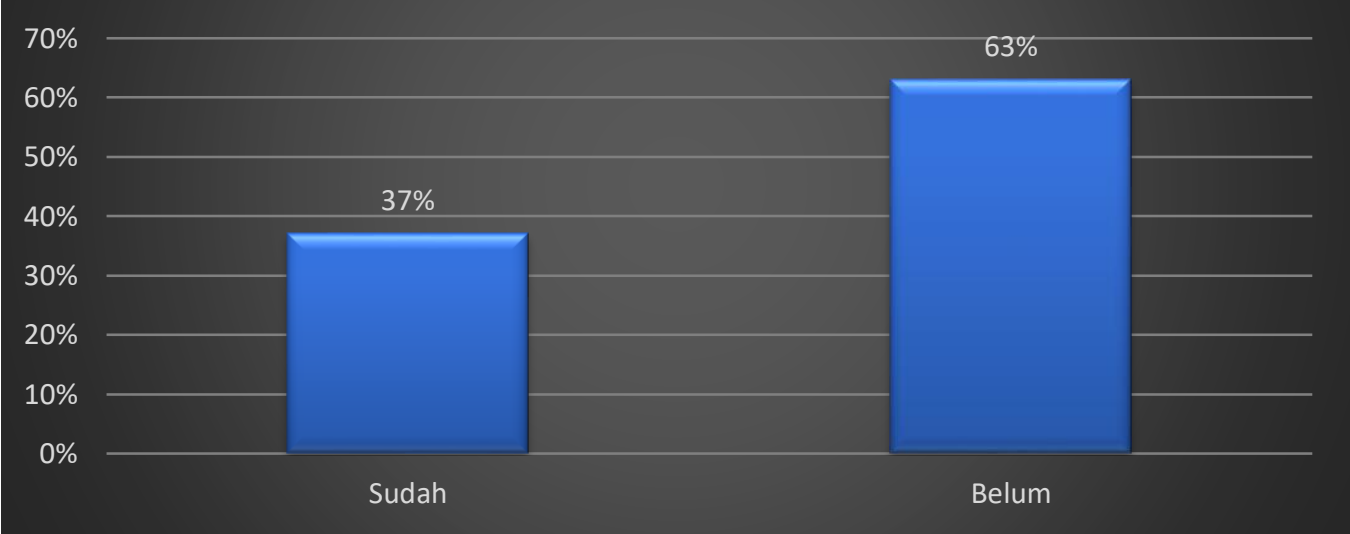

Gambar 2 Respon keefektifan dari pembelajaran daring.

Kurang efektifnya pembelajaran daring menurut peserta didik dapat disebabkan oleh perubahan sistem belajar yang sebelumnya konvensional menjadi sistem daring dengan sangat mendadak tanpa adanya persiapan matang sehingga banyak kendala yang dijumpai selama masa adaptasi (Hidayah dkk., 2020). Eva Maizarra Puspita Dewi, seorang psikolog Pendidikan (Mustakim, 2020) mengemukakan bahwa secara umum terdapat tiga reaksi perilaku individu saat berhadapan dengan bahaya, pertama dia akan menolak, kemudian melakukan tawar menawar dan terakhir menerima dan beradaptasi. Jika saat ini peserta didik masih merasa bahwa pembelajaran daring kurang atau belum efektif, mungkin suatu saat peserta didik sudah dapat menyesuaikan diri dan mulai terbiasa dengan sistem belajar via online seiring dengan berkembangnya teknologi. Dalam penelitian Lanusi (2018) didapati bahwa penerapan kelas digital dapat mencapai ketuntasan belajar dan terjadi peningkatan yang signifikan pada minat dan hasil belajar peserta didik.

\section{Akses yang Digunakan Selama Pembelajaran Daring}

Akses yang paling banyak digunakan saat pembelajaran daring dimasa pandemi COVID-19 pada jenjang menengah hingga perguruan tinggi secara berturut-turut yakni google classroom dengan persentase sebesar $72,9 \%$, pembelajaran via group chat (WA/line) sebesar $62,7 \%$, pembelajaran virtual melalui zoom sebesar 35,6\%, akses pembelajaran melalui youtube sebesar 29,7\% , akses edmodo sebesar 18,6\%, Quipper sebesar 1,7\%, Googleform sebesar 1,7\% serta lainnya dengan masing-masing 1\%.(Gambar 3) 


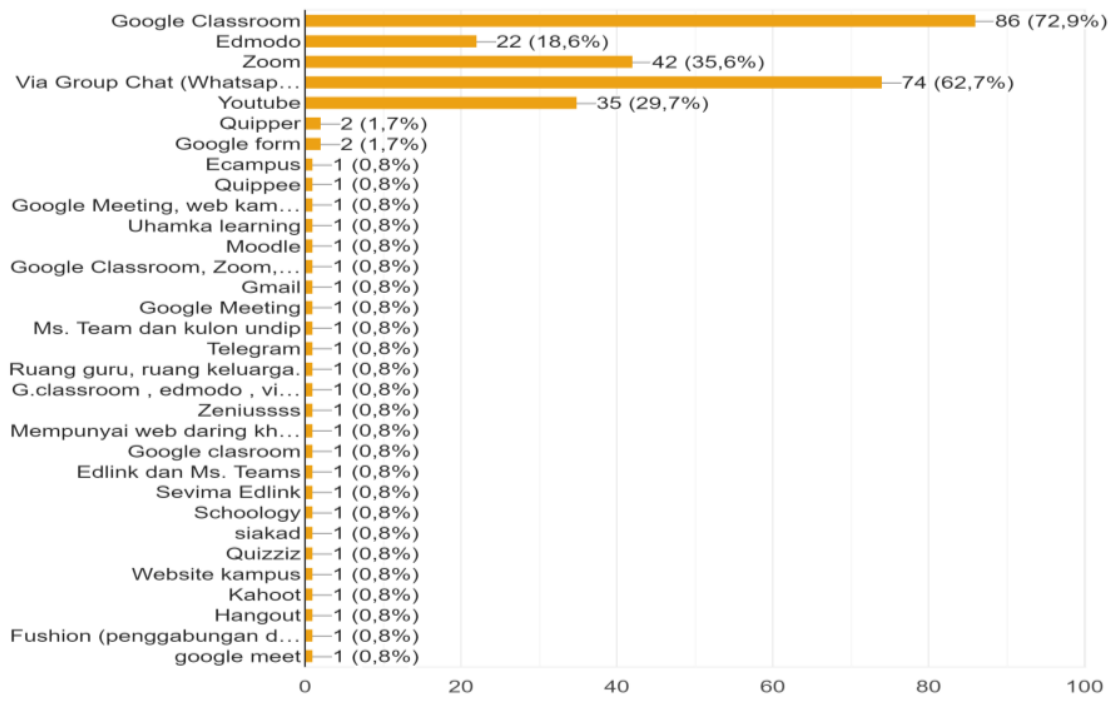

Gambar 3 Akses yang digunakan selama pembelajaran daring

Google classroom atau ruang kelas Google menjadi akses yang paling banyak dipilih oleh responden dalam membantu berjalannya pembelajaran daring. Dalam penelitian Mustakim (2020) Google classroom menjadi media yang paling disukai oleh peserta didik sebagai media pembelajaran daring dikarenakan penggunaanya yang dianggap mudah dan praktis. Salah satu fitur Google for Education ini memberikan kemudahan tenaga pendidik dalam merancang, men-share, mengelompokkan penugasan dan menyimpan hasil dengan langsung terhubung ke Google drive. Tugas yang dikumpulkan berupa dokumen tanpa kertas biasa disebut dengan paperless (Komariah dkk., 2019). Google Classroom telah dirancang untuk kemudahan empat pengguna yaitu tenaga pendidik, peserta didik, wali, dan administrator. Tenaga pendidik dapat membuat dan mengelola kelas, memberikan nilai, mengirimkan tugas dengan deadline, serta memberikan masukan secara langsung (realtime). Peserta didik dapat memantau materi atau tugas yang diberikan dengan pemberitahuan via email, berbagi dokumen dan berinteraksi dengan teman-teman kelas serta bertanya kepada guru, mengirim tugas dan mendapat penilaian serta tanggapan secara langsung. Wali yang didaftarkan juga bisa mendapatkan ringkasan email terkait tugas peserta didik untuk memantau hasil pembelajaran anaknya. Administrator dapat membuat, mengatur, memantau atau menghapus kelas di domain serta menambah atau mengeluarkan akun peserta didik maupun tenaga pendidik.

Menurut responden, kelebihan dari Google Classroom yaitu memudahkan dalam mengakses materi, tugas, serta pengumpulannya. Bahkan terdapat pengingat waktu untuk pengumpulan tugas dan dapat berkomunikasi secara personal kepada tenaga pendidik yang terkait. Berdasarkan hasil penelitian (Komariah dkk., 2019) penggunaan media pembelajaran Google Classroom dapat memberikan pengaruh terhadap minat dan hasil belajar peserta didik.

Selain kelebihan tersebut, ternyata media pembelajaran Google Classroom memiliki beberapa kekurangan. Hal itu disampaikan oleh beberapa responden yang mengatakan bahwa penggunaan Google Classroom menghabiskan kuota data internet yang tidak sedikit sehingga pengeluaran ekonomi bertambah. Hasil penelitian Endah Wulantina (2019) juga menyebutkan bahwa proses pembelajaran melalui Google Classroom kurang efisien dari segi biaya yang relatif cukup besar untuk membeli paket data internet. Namun hal ini dapat disikapi dengan meminimalisir pemberian materi dengan video atau file yang berkapasitas besar.

\section{Faktor yang Mempengaruhi Pembelajaran Daring}

Berdasarkan hasil kuisioner, efektivitas kegiatan pembelajaran secara daring berturut-turut dipengaruhi oleh faktor ekonomi sebanyak 38\%, faktor sosial sebanyak 30\%, faktor kesehatan sebanyak $19 \%$ dan kepribadian sebanyak 13\%. (Gambar 4) 


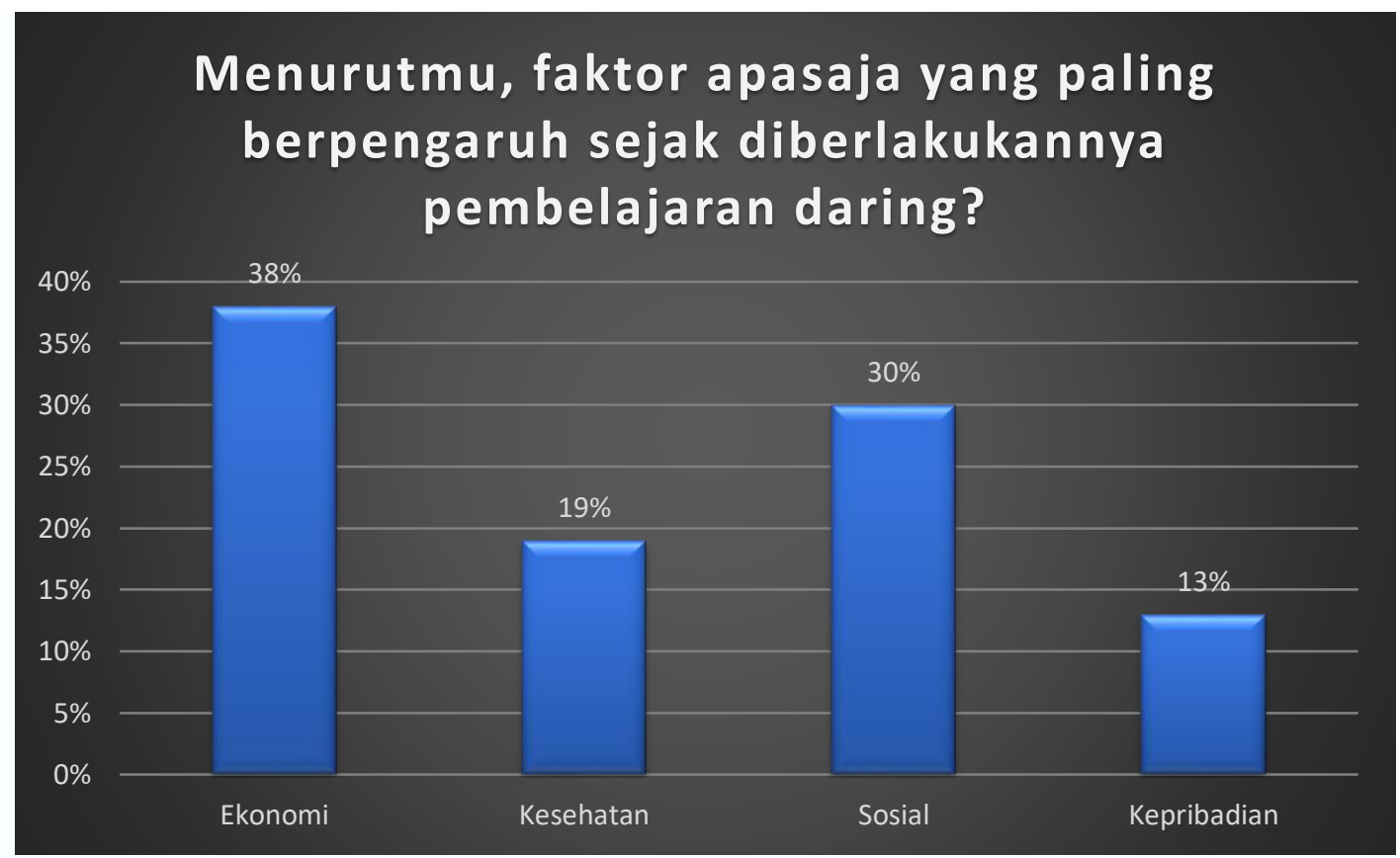

Gambar 4 Faktor yang mempengaruhi pembelajaran daring.

Faktor-faktor tersebut saat ini banyak dirasakan oleh masyarakat yang berada dalam ruang lingkup pendidikan. Banyak diantara mereka yang belum terbiasa atau baru melaksanakan proses pembelajaran secara daring baik bagi sekolah, guru ataupun peserta didik sehingga memberikan dampak tersendiri bagi keefektifan proses pembelajaran. Mayoritas dari responden mengeluh mengenai pembelajaran daring karena sistem pembelajaran ini diterapkan secara mendadak tanpa ada pelatihan sebelumnya. Namun pembelajaran daring tetap memiliki aspek positif yang dapat diambil (Suriadi dkk., 2021).

Berdasarkan hasil isian singkat responden terhadap aspek postif dan negatif pembelajaran daring, diperoleh sisi positif dan negatif dari masing-masing faktor. Aspek negatif pada faktor ekonomi menurut responden adalah pembelajaran daring lebih banyak mengeluarkan biaya karena pencarian materi yang sesuai, pembelajaran via akses virtual, submit tugas dan urusan lainnya saat ini membutuhkan akses internet yang maksimal dan tentunya menghabiskan banyak kuota. Adapun aspek positifnya adalah dapat lebih menghemat pengeluaran uang saku dan transportasi, bagi mahasiswa juga sudah tidak perlu menanggung biaya sewa kosan. Aspek negatif pembelajaran daring pada faktor sosial adalah menghambat proses komunikasi secara langsung sehingga sering terjadi misskomunikasi maupun misskonsepsi. Beberapa responden juga menyatakan perasaan kurang nyaman saat berkomunikasi secara daring karena merasa akan mendapat jawaban/penyelesaian yang kurang maksimal sehingga malas untuk bertanya. Kurangnya interaksi inilah yang bisa memperlambat terbentuknya konsep saat proses belajar mengajar. Aspek positif dari faktor sosial ini adalah dapat mendekatkan diri dan berinteraksi lebih banyak dengan keluarga, dapat mematuhi protokol Kesehatan sehingga lebih aman untuk berinteraksi, mendapatkan lebih banyak teman melalui forum-forum dan webinar dari segala sisi.

Dari segi kesehatan, aspek negatif pembelajaran daring yang banyak dirasakan oleh responden adalah mata terasa lelah karena sering membuka laptop/computer/gawai untuk mengerjakan tugas, kelelahan, badan pegal-pegal karena jarang bergerak dan perasaan tertekan dengan banyaknya tugas yang perlu dikerjakan. Hal ini sejalan dengan penelitian Putria dkk. (2020) tentang banyaknya keluhan terkait tugas yang terlalu banyak diberikan oleh guru selama pembelajaran daring. Aspek positif dari segi kesehatan adalah pengerjaan tugas dan akses pembelajaran dapat dilakukan dirumah sehingga dapat menghindari resiko dari terkena COVID-19. Aspek negatif pembelajaran secara daring pada kepribadian adalah kemampuan bersosialisasi yang semakin berkurang karena kurangnya interaksi dan bingung dengan pengaturan jadwal yang tidak sesuai dengan jadwal 
awal. Adapun aspek positifnya adalah disiplin, melatih rasa tanggung jawab dan multitasking dengan banyaknya tugas sekolah serta kewajiban rumah yang harus diselesaikan.

Pembelajaran daring ternyata memliki aspek positif yang dapat diambil, namun hal tersebut sepertinya belum banyak dirasakan oleh orang yang berada diruang lingkup pendidikan karena masih banyak tenaga pendidik dan peserta didik yang belum mampu beradaptasi dan merasa kesulitan untuk memahami sistem pembelajaran daring ini. Menurut Pangodian dkk (2019), penerapan pembelajaran daring akan berjalan optimal jika diikuti oleh beberapa faktor pendukung dimensi sistem, yaitu berupa kualitas sistem dan infrastruktur, kualitas informasi dan pembelajaran serta kualitas lembaga pelayanan. Sehingga, pembaruan pada sistem yang dapat mendukung adanya interaksi dan penugasan yang sewajarnya sebetulnya sudah dapat mengurangi aspek negatif diatas yang akan berpengaruh terhadap kenaikan efektifitas pembelajaran daring. Di Indonesia, regulasi memang menjadi hal mendasar yang harus diselesaikan melalui permenristekdikti untuk mengatur dan menjadi acuan bagi sekolah maupun perguruan tinggi untuk mulai mempromosikan sistem pembelajaran daring atau e-learning.

\section{Saran Peneliti Terhadap Proses Pelaksanaan Pembelajaran Daring}

Dari data di atas, mayoritas peserta didik masih merasakan bahwa pembelajaran daring di sekolahnya belum efektif. Hal ini bertentangan dengan hasil penelitian (Abidin, 2020; Kusmaharti \& Yustitia, 2020; Mustakim, 2020) yang menyatakan bahwa proses pembelajaran daring sudah efektif. Sehingga, peneliti merangkum berbagai tanggapan dari para responden untuk dijadikan bahan pertimbangan guru/dosen khususnya di wilayah Kabupaten Bekasi dalam melaksanakan pembelajaran daring kedepan supaya lebih efektif di masa pandemi COVID-19 ini, yaitu: 1) meringkas materi belajar yang perlu di unduh; 2) menghemat kuota dengan hanya menggunakan virtual meeting sebagai media untuk menjelaskan teori yang sekiranya sulit dipahami; 3) menghindari pemberian tugas yang berlebihan; 4) Selalu menanyakan kepada peserta didik terkait materi yang kurang dimengerti secara berkelompok/individu untuk mengurangi misskonsepsi; 5) memberikan informasi terkait forum-forum diskusi/webinar untuk melatih beradaptasi daring; 6) melaksanakan pembelajaran sesuai dengan jadwal; 7) menggunakan sistem/platform yang sama sebagai media pembelajaran daring.

\section{KESIMPULAN}

Pembelajaran daring yang diberlakukan untuk mematuhi kebijakan pemerintah terkait physical distancing merupakan pelaksanaan proses belajar mengajar dengan memanfaatkan jaringan internet tanpa terbatas oleh ruang dan waktu. Dari hasil kuisioner, hampir seluruh sekolah jenjang menengah hingga perguruan tinggi telah melakukan pembelajaran daring. Namun, pembelajaran daring itu sendiri masih dinilai belum efektif oleh sebagian besar peserta didik dikarenakan pelaksanaannya yang mendadak sehingga perlu dilakukan adaptasi media terlebih dahulu. Berdasarkan hasil kuisioner, akses yang paling banyak digunakan sebagai media pembelajaran daring adalah google classroom dengan persentase sebesar $72,9 \%$. Google classroom menjadi platform yang paling digemari dikarenakan fitur-fitur didalamnya yang mudah dan praktis. Kekurangannya adalah pada pemakaian kuota data yang tidak sedikit jika digunakan untuk mengunduh file yang besar. Hasil survei juga menunjukan bahwa efektifitas dari pembelajaran daring ternyata dipengaruhi oleh beberapa faktor yaitu; faktor ekonomi sebesar 38\%, faktor sosial sebesar 30\%, faktor Kesehatan sebesar $19 \%$ dan faktor kepribadian sebesar $13 \%$. Untuk membuat pembelajaran daring menjadi lebih efektif, tenaga pendidik perlu memperhatikan masukan dari para peserta didik, yaitu: 1) meringkas materi belajar yang perlu di unduh; 2) menghemat kuota dengan hanya menggunakan virtual meeting sebagai media untuk menjelaskan teori yang sekiranya sulit dipahami; 3) menghindari pemberian tugas yang berlebihan; 4) Selalu menanyakan kepada peserta didik terkait materi yang kurang dimengerti secara berkelompok/individu untuk mengurangi 
misskonsepsi; 5) memberikan informasi terkait forum-forum diskusi/webinar untuk melatih beradaptasi daring; 6) melaksanakan pembelajaran sesuai dengan jadwal; 7) menggunakan sistem/platform yang sama sebagai media pembelajaran daring.

\section{UCAPAN TERIMA KASIH}

Terimakasih saya ucapkan kepada semua pihak yang telah berkontribusi dalam penelitian ini, khususnya kepada teman-teman almamater, dosen pembimbing penelitian, teman-teman mahasiswa serta adik-adik SMP dan SMA yang turut berpartisipasi dalam mengisi kuisioner peneliti sehingga penelitian ini dapat terlaksana dengan baik.

\section{DAFTAR PUSTAKA}

Abidin, Z., Hudaya, A., \& Anjani, D. (2020). Efektivitas Pembelajaran Jarak Jauh Pada Masa Pandemi Covid19. Research and Development Journal of Education, 1(1), 131. https://doi.org/10.30998/rdje.v1i1.7659

Bilfaqih, Y., \& Qomarudin, M. N. (2015). Esensi Pengembangan Pembelajaran Daring (1st ed.). Yogyakarta: Deepublish Publisher.

Burhan, F. A. (2020). Ruangguru, Zenius dan Quipper Beri layanan Belajar Gratis Efek Corona [online]. Tersedia : https://katadata.co.id/berita/2020/03/16/ruangguru-zenius-dan-quipper-beri-layananbelajar-gratis-efek-corona

Daheri, M., Juliana, J., Deriwanto, D., \& Amda, A. D. (2020). Efektifitas WhatsApp sebagai Media Belajar Daring. Jurnal Basicedu, 4(4), 775-783. https://doi.org/10.31004/basicedu.v4i4.445

Dewi, W. A. F. (2020). Dampak COVID-19 terhadap Implementasi Pembelajaran Daring di Sekolah Dasar. Edukatif: Jurnal Ilmu Pendidikan, 2(1), 55-61. https://doi.org/10.31004/edukatif.v2i1.89

Endah Wulantina, S. M. (2019). Persepsi Peserta Didik terhadap Metode Blended Learning dengan Google Classroom. Jurnal Inovasi Matematika, 1(2), 110-121. https://doi.org/10.35438/inomatika.v1i2.156

Hidayah, A. A. F., Al Adawiyah, R., \& Mahanani, P. A. R. (2020). Efektivitas Pembelajaran Daring di Masa Pandemi Covid 19. JURNAL SOSIAL:Jurnal Penelitian Ilmu-Ilmu Sosial, 21(September), 53-56. Retrieved from http://sosial.unmermadiun.ac.id/index.php/sosial/article/view/61

Komariah, N., Mujasam, Yusuf, I., \& Widyaningsih, S. W. (2019). Pengaruh penerapan model PBL berbantuan media GOOGLE CLASSROOM terhadap HOTS, motivasi dan minat peserta didik. Silampari Jurnal Pendidikan Ilmu Fisika, 1(2), 102-114. Retrieved from doi: https://doi.org/10.31540/sjpif.v1i2.788 https://ojs.stkippgri-lubuklinggau.ac.id/index.php/SJPIF PENGARUH

Kurniasari, A., Pribowo, F. S. P., \& Putra, D. A. (2020). Analisis Efektivitas Pelaksanaan Belajar Dari Rumah (Bdr) Selama Pandemi Covid-19. Jurnal Review Pendidikan Dasar: Jurnal Kajian Pendidikan Dan Hasil Penelitian, 6(3), 1-8.

Kusmaharti, D., \& Yustitia, V. (2020). Efektivitas Online Learning terhadap Kemampuan Pemecahan Masalah Matematika Mahasiswa. Journal of Medives : Journal of Mathematics Education IKIP Veteran Semarang, 4(2), 311. https://doi.org/10.31331/medivesveteran.v4i2.1199

Laili, R. N., \& Nashir, M. (2021). Higher Education Students 'Perception on Online Learning during Covid19 Pandemic. Edukatif: Jurnal Ilmu Pendidikan, 3(3), 689-697.

Lanusi, D. H. (2018). PENERAPAN KELAS DIGITAL EDMODO UNTUK MENINGKATKAN MINAT BELAJAR DAN HASIL BELAJAR SISWA. Jurnal Didaktika Pendidikan Dasar, 2(1), 67-82. Retrieved

from https://doi.org/10.1016/j.tmaid.2020.101607\%0Ahttps://doi.org/10.1016/j.ijsu.2020.02.034\%0Ahttps://o 
889 Analisis Efektifitas Pembelajaran Daring Dalam Menghadapi Wabah Pandemic Covid-19- Dwinda Nur Baety, Dadang Rahman Munandar

DOI: https://doi.org/10.31004/edukatif.v3i3.476

nlinelibrary.wiley.com/doi/abs/10.1111/cjag.12228\%0Ahttps://doi.org/10.1016/j.ssci.2020.104773\%0Ah ttps://doi.org/10.1016/j.jinf.2020.04.011\%0Ahttps://doi.o

Mustakim, M. (2020). Efektivitas Pembelajaran Daring Menggunakan Media Online Selama Pandemi Covid19 Pada Mata Pelajaran Matematika. Al Asma: Journal of Islamic Education, 2(1), 1. https://doi.org/10.24252/asma.v2i1.13646

Pangodian, R. A., Santosa, P. I., \& Nugroho, E. (2019). Faktor - Faktor Yang Mempengaruhi Kesuksesan Pembelajaran Daring Dalam Revolusi Industri 4.0. Sainteks 2019, 56-60. Retrieved from https://seminar-id.com/semnas-sainteks2019.html

Putria, H., Maula, L. H., \& Uswatun, D. A. (2020). Analisis Proses Pembelajaran dalam Jaringan (DARING) Masa Pandemi Covid- 19 Pada Guru Sekolah Dasar. Jurnal Basicedu, 4(4), 861-870. https://doi.org/10.31004/basicedu.v4i4.460

Salim, \& Haidir. (2019). Penelitian Pendidikan: Metode, Pendekatan, dan Jenis. Jakarta: Penerbit Kencana.

Santoso, B. (2020). Prosach: Sebagai Acuan Pembelajaran Matematika Dengan Menggunakan Platform Digital Di Masa Pandemik Covid-19. LINEAR: Journal of Mathematics Education, 1(1), 57-63. Retrieved from http://e-journal.metrouniv.ac.id/index.php/linear/article/view/2224

Sugiyono. (2015). Metode Penelitian Pendidikan (Pendekatan Kuantitatif, Kualitatif dan R\&D). In -. Bandung: Alfabeta.

Suriadi, H. J., Firman, F., \& Ahmad, R. (2021). Analisis Problema Pembelajaran Daring Terhadap Pendidikan Karakter Peserta Didik. Edukatif: Jurnal Ilmu Pendidikan, 3(1), 165-173.

Wisudawati, N., Kuntarto, E., \& Kurniawan, A. R. (2020). PERSEPSI GURU TERHADAP APLIKASI EDMODO SEBAGAI ALAT BANTU KEGIATAN BELAJAR DI SEKOLAH DASAR. Jurnal Riset Pendidikan Dasar, 03(1), 87-96.

Yunitasari, R., \& Hanifah, U. (2020). Pengaruh Pembelajaran Daring terhadap Minat Belajar Siswa pada Masa COVID 19. Edukatif: Jurnal Ilmu Pendidikan, 2(3), 232-243. https://doi.org/10.31004/edukatif.v2i3.142 